GOSPODARKA SUROWCAMI MINERALNYMI - MINERAL RESOURCES MANAGEMENT

\title{
Wpływ właściwości fizykochemicznych stałych pozostałości z termicznego przekształcania osadów ściekowych na możliwość ich wykorzystania w ceramice czerwonej
}

\section{Wprowadzenie}

Produkcja wyrobów ceramicznych związana jest z wykorzystaniem surowców naturalnych w postaci glin, piasków czy skaleni (Galos 2008). Niestety, pozyskanie tych surowców nie dość, że zmniejsza ich zasoby to niekorzystnie wpływa na środowisko naturalne. Względy ochrony środowiska jak i rozwój przemysłu budowlanego powodują, że producenci wyrobów ceramicznych coraz częściej wykorzystują odpady jako składniki mas plastycznych. Do najczęściej wykorzystywanych odpadów do produkcji wyrobów ceramicznych należą: popiół lotny i żużel ze spalania i współspalania węgla z biomasą, popioły lotne i żużle z termicznego przekształcania odpadów komunalnych, łupki towarzyszące wydobyciu węgla (Cheng i Chen 2004; Gunn i in. 2004; Lin 2006; Cultrone i Sebastián 2009; Ahmaruzzaman 2010; Zhang 2013). W zależności od właściwości fizykochemicznych, odpady mogą częściowo zastępować surowce plastyczne, schudzające czy topniki (Lin i Weng 2001; Anderson i Skerratt 2003; Weng i in. 2003; Lin 2006). Wykorzystanie odpadów ma także wpływ na technologię produkcji jak i oddziaływanie zakładów ceramicznych na środowisko.

Oczywiście w przypadku wykorzystania odpadów występują ograniczenia związane z procesem technologicznym warunkowane recepturą masy plastycznej jak i wynikające

* Dr inż., ** Mgr inż., AGH Akademia Górniczo-Hutnicza, Wydział Górnictwa i Geoinżynierii, Kraków; e-mail: kepys@agh.edu.pl 
z wymagań stawianych materiałom stosowanym w przemyśle ceramicznym. Materiały takie muszą się charakteryzować niską zawartością tlenków barwiących w przypadku ceramik białowypalających się $\left(\mathrm{Fe}_{2} \mathrm{O}_{3}\right.$ do $1 \% \mathrm{i} \mathrm{TiO}_{2}$ do $\left.0,3 \%\right)$ oraz niewielką ilością soli rozpuszczalnych. Niespełnianie określonych wymagań przez materiały (na przykład obecność rozpuszczalnych siarczanów, chlorków) może powodować wady gotowych wyrobów, takie jak wykwity solne na powierzchni klinkieru (Gunn i in. 2004; Małolepszy red. 2004).

W artykule przedstawiono wyniki badań właściwości fizykochemicznych stałych pozostałości pochodzących z instalacji termicznego przekształcania komunalnych osadów ściekowych (TPKOŚ) - popiołów lotnych oraz pozostałości z oczyszczania spalin. Zgodnie z katalogiem odpadów (Rozporządzenie MŚ 2001) są one klasyfikowane pod kodem 190114 - popioły lotne inne niż wymienione w 1901 13, natomiast pozostałości z suchego oczyszczania gazów klasyfikuje się pod kodem $190107^{*}$ - odpady stałe z oczyszczania gazów odlotowych (odpad niebezpieczny).

Ponieważ od 2016 roku zakazuje się składowania komunalnych osadów ściekowych (Rozporządzenie MG 2013), od kilku lat w Polsce przybywa instalacji do ich termicznego przekształcenia. Jak podaje GUS, w 2010 roku termicznemu przekształceniu poddano 19,8 tys. Mg s.m. komunalnych osadów ściekowych, natomiast w 2012 roku ilość ta wzrosła do 56,6 tys. Mg s.m. (GUS 2013), czego następstwem było powstanie w 2012 r. ponad 22 tys. Mg stałych pozostałości z procesów oczyszczania spalin. Na świecie większość tego rodzaju odpadów jest obecnie składowana (Donatello i Cheeseman 2013). Zgodnie z hierarchią postępowania $\mathrm{z}$ odpadami istnieje potrzeba poszukiwania możliwości ich zagospodarowania. Prowadzone są badania dotyczące wykorzystania tego rodzaju odpadów jako źródła fosforu (w produkcji nawozów, w przemyśle chemicznym) (Wzorek 2008; Xu 2012; Donatello i Cheeseman 2013; Ottosen i in. 2013; Weigand i in. 2013; Iżewska i Wołoszczyk), w budownictwie (Wainwright i Cresswell 2001; Monzó i in. 2003; Cyr i in. 2007; Borowski 2012) czy technologiach górniczych (Pietrzyk 2012; Kępys i in. 2014).

Celem badań było przeanalizowanie właściwości stałych pozostałości z termicznego przekształcania komunalnych osadów ściekowych pod kątem zastosowania ich w produkcji cegiel.

\section{Materiały i metodyka badań}

Przedmiotem badań były stałe pozostałości powstające w trzech różnych instalacjach TPKOŚ na terenie Polski. We wszystkich instalacjach spalanie osadów ściekowych odbywa się w kotłach fluidalnych. Zbadano trzy próbki popiołów lotnych, oznaczonych jako K1, G2, L1, oraz dwie próbki odpadów z procesów oczyszczania spalin, oznaczone jako KN1, LN1. Próbki popiołów lotnych K1, G2 i L1 pochodziły z multicyklonów i elektrofiltrów, natomiast odpady z oczyszczania gazów spalinowych z kwaśnych zanieczyszczeń gazowych $\left(\mathrm{HCl}, \mathrm{SO}_{\mathrm{x}}, \mathrm{HF}, \mathrm{NO}_{\mathrm{x}}\right)$ i metali ciężkich z filtrów workowych. 
Wykonano następujące badania właściwości fizykochemicznych.

- skład ziarnowy oznaczono metodą dyfrakcji laserowej przy użyciu aparatu Analysette 22 firmy Fritsch;

- gęstość właściwą określono metodą piknometryczną za pomocą piknometru helowego Micrometrics Multivolume Pycnometer;

- skład chemiczny oznaczono za pomocą spektrometru masowego z plazmą wzbudzoną indukcyjnie (ICP-MS) oraz spektrofotometru emisyjnego z plazmą wzbudzoną indukcyjnie (ICP-OES). Badane próbki roztwarzano przy użyciu $\mathrm{HNO}_{3} / \mathrm{HCl}$ oraz mineralizatora mikrofalowego;

- skład fazowy oznaczono metodą rentgenograficzną aparatem Philips APD X'Pert PW 2030 ,

- promieniotwórczość, oznaczenie naturalnych stężeń ${ }^{40} \mathrm{~K},{ }^{226} \mathrm{Ra}$ i ${ }^{232} \mathrm{Th}$ wykonano przy użyciu scyntylacyjnej i półprzewodnikowej spektometrii promieniowania gamma,

- wymywalność zanieczyszczeń chemicznych przeprowadzono zgodnie z PN-EN 12457-2. Odpady mieszano $z$ wodą destylowaną w stosunku 1/10. Całość była wytrząsana w plastikowej butelce przez $24 \mathrm{~h}$, następnie przefiltrowana przez filtr o wielkości $0,45 \mu \mathrm{m}$. Dla wyciągu wodnego określono $\mathrm{pH}$ oraz zawartość zanieczyszczeń za pomocą ICP-OES oraz ICP-MS. Zawartość chlorków oznaczono wykorzystując metodę miareczkową (Mohra).

\section{Wyniki badań}

\subsection{Właściwości fizyczne}

Gęstość właściwa dla wszystkich próbek badanych stałych pozostałości z TPKOŚ zawierała się $w$ granicach $2,46 \mathrm{~g} / \mathrm{cm}^{3}$ do $2,94 \mathrm{~g} / \mathrm{cm}^{3}$.

Maksymalna wielkość ziaren popiołów dla popiołów K1, G2 i L1 dochodziła $280 \mu \mathrm{m}$, natomiast dla odpadów KN1 i LN1 była niższa, wynosiła odpowiednio $120 \mu \mathrm{m}$ i $180 \mu \mathrm{m}$ rysunek 1 . Skład ziarnowy ma decydujący wpływ na uplastycznianie się masy do wyrobu ceramiki czerwonej, w celu otrzymania najściślejszej masy zaleca się następujący skład granulometryczny: $25 \%$ frakcji $2-3 \mathrm{~mm}, 25 \%$ frakcji $1-2 \mathrm{~mm}, 50 \%$ frakcji poniżej $1 \mathrm{~mm}$ (Małolepszy red. 2004). Wobec powyższego badane stałe pozostałości z TPKOŚ moga stanowić najdrobniejszą frakcję w masie ceramicznej.

Wartości naturalnych izotopów promieniotwórczych przedstawiono w tabeli 1. Zgodnie $\mathrm{z}$ rozporządzeniem w sprawie wymagan dotyczących zawartości naturalnych izotopów promieniotwórczych w surowcach i materiałach stosowanych w budynkach przeznaczonych na pobyt ludzi i inwentarza żywego, a także $\mathrm{w}$ odpadach przemysłowych stosowanych w budownictwie, oraz kontroli zawartości tych izotopów (Rozporządzenie RM 2013), wartości wskaźników aktywności $\mathrm{f}_{1}$ i $\mathrm{f}_{2}$ nie mogą przekraczać o więcej niż $20 \%$ wartości 


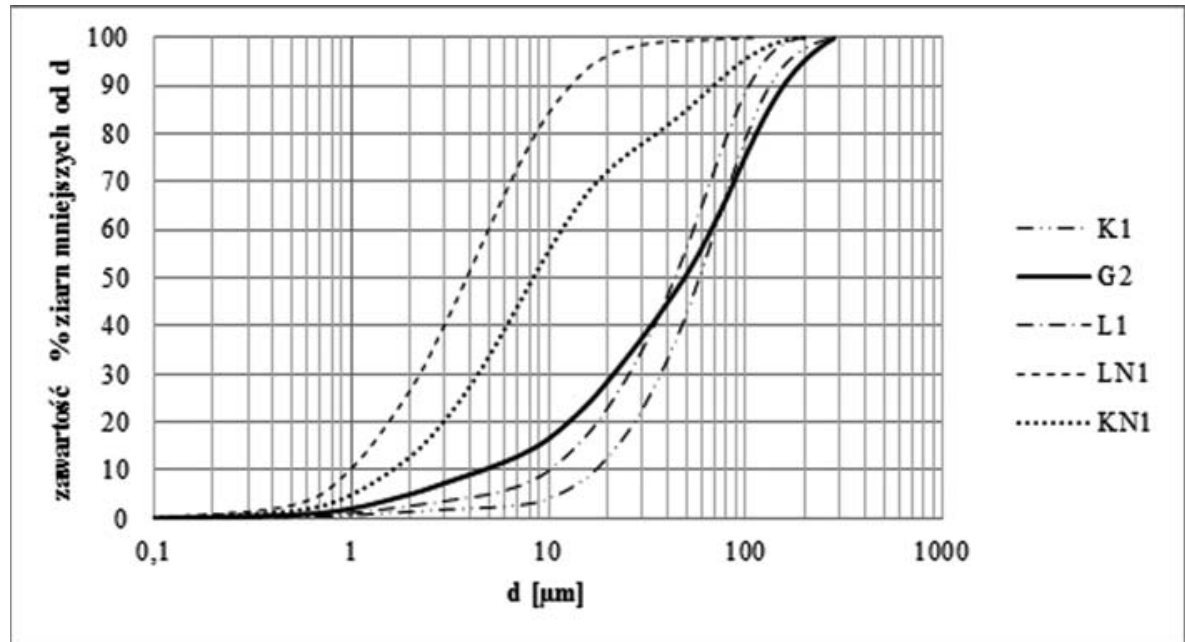

Rys. 1. Skład ziarnowy stałych pozostałości ze spalania komunalnych osadów ściekowych

Fig. 1. Particle size distribution of incinerated sewage sludge solid residues

Tabela 1. Zawartość naturalnych izotopów promieniotwórczych w stałych pozostałościach ze spalania komunalnych osadów ściekowych

Table 1. Radioactivity of incinerated sewage sludge solid residues

\begin{tabular}{|c|c|c|c|c|c|c|}
\hline \multirow{3}{*}{$\begin{array}{c}\text { Symbol } \\
\text { badanej } \\
\text { próbki }\end{array}$} & \multicolumn{3}{|c|}{ Aktywność właściwa } & \multirow[b]{2}{*}{$f_{1}$} & \multirow[b]{2}{*}{$\mathrm{f}_{2}$} & \multirow{2}{*}{$\begin{array}{c}\text { Aktywność } \\
\text { właściwa } \\
{ }^{226} \mathrm{Ra}+{ }^{228} \mathrm{Ra}\end{array}$} \\
\hline & ${ }^{40} \mathrm{~K}$ & ${ }^{226} \mathrm{Ra}$ & $\begin{array}{c}{ }^{228} \mathrm{Th} \\
\left({ }^{228} \mathrm{Ra}\right)\end{array}$ & & & \\
\hline & {$[\mathrm{Bq} / \mathrm{kg}]$} & {$[\mathrm{Bq} / \mathrm{kg}]$} & {$[\mathrm{Bq} / \mathrm{kg}]$} & - & {$[\mathrm{Bq} / \mathrm{kg}]$} & {$[\mathrm{Bq} / \mathrm{kg}]$} \\
\hline G2 & $388 \pm 20$ & $52 \pm 3$ & $26 \pm 2$ & $0.43 \pm 0.02$ & $52 \pm 3$ & $78 \pm 4$ \\
\hline $\mathrm{K} 1$ & $512 \pm 27$ & $76 \pm 4$ & $32 \pm 3$ & $0.58 \pm 0.02$ & $76 \pm 4$ & $108 \pm 5$ \\
\hline L1 & $410 \pm 25$ & $94 \pm 6$ & $34 \pm 2$ & $0.62 \pm 0.02$ & $94 \pm 6$ & $190 \pm 8$ \\
\hline KN1 & $175 \pm 11$ & $26 \pm 2$ & $12 \pm 2$ & $0.21 \pm 0.01$ & $26 \pm 2$ & $38 \pm 3$ \\
\hline LN1 & $152 \pm 11$ & $42 \pm 3$ & $13 \pm 2$ & $0.26 \pm 0.01$ & $42 \pm 3$ & $83 \pm 4$ \\
\hline
\end{tabular}

$\mathrm{f}_{1}=1 \mathrm{i} \mathrm{f}_{2}=200 \mathrm{~Bq} / \mathrm{kg}$. Badane stałe pozostałości po spalaniu osadów ściekowych spełniają wymienione wymagania, a więc mogą być dopuszczone do produkcji materiałów budowlanych stosowanych w budynkach przeznaczonych na stały pobyt ludzi. 


\subsection{Skład chemiczny}

Stałe pozostałości ze spalania komunalnych osadów ściekowych zawierają głównie krzem fosfor i wapń. Ogólnie ich skład chemiczny jest zróżnicowany i zależy od instalacji, z której próbka została pobrana, jak i rodzaju odpadu - tabela 2. Zawartość krzemionki dla popiołu lotnego K1 dochodzi do 43\%, niższą, wynoszącą 34\% określono dla popiołu L1, który wydaje się być dobrym materiałem schudzającym. Zawartość pierwiastków alkalicznych ( $\mathrm{Na}, \mathrm{K}, \mathrm{Ca}, \mathrm{Mg}$ ) wpływa na temperaturę spiekania wyrobów (działa obniżająco), wobec tego z punktu widzenia technologii produkcji ich obecność jest zjawiskiem korzystnym. Z drugiej strony metale alkaliczne i ziem alkalicznych powinny być wprowadzone do układu w postaci krzemianów bądź glinokrzemianów.

Obecność tlenków barwiących, takich jak tlenek tytanu i tlenek żelaza maksymalnie wynoszą odpowiednio 0,08 i 4,78\%, co nie stanowi przeszkód do stosowania stałych pozostałości TPKOŚ w ceramice czerwonej. Dopuszczalne ilości tych tlenków w masie ceramicznej czerwonej są warunkowane recepturą masy, a ich zawartość może dochodzić do kilkunastu procent (Lin i Weng 2001; Anderson i Skerratt 2003; Weng i in. 2003; Gunn i. in. 2004; Lin 2006). Wysokie zawartości siarczanów dla KN1 i LN1, wynikające z procesu oczyszczania spalin (stosowanie wodorowęglanu sodu), mogą być poważnym utrudnieniem w technologii produkcji cegieł, wręcz wykluczającym ich stosowanie jako składników mas plastycznych. Ponieważ forma rozpuszczalna siarczanów powoduje powstawanie wad materiałowych w postaci białych wykwitów solnych na powierzchni wyrobów, siarczany

Tabela 2. Skład chemiczny stałych pozostałości ze spalania komunalnych osadów ściekowych [\% mas.]

Table 2. Chemical composition of incinerated sewage sludge solid residues [\% wt.]

\begin{tabular}{|c|c|c|c|c|c|}
\hline \multirow{2}{*}{ Składnik } & \multicolumn{5}{|c|}{ Próbka } \\
\cline { 2 - 6 } & $\mathrm{G} 2$ & $\mathrm{~K} 1$ & $\mathrm{KN} 1$ & $\mathrm{~L} 1$ & LN1 \\
\hline $\mathrm{SiO}_{2}$ & 21,00 & 43,20 & 9,90 & 34,5 & 1,60 \\
\hline $\mathrm{Al}_{2} \mathrm{O}_{3}$ & 13,75 & 4,96 & 1,94 & 4,18 & 2,02 \\
\hline $\mathrm{CaO}$ & 17,80 & 21,27 & 6,28 & 17,95 & 7,47 \\
\hline $\mathrm{MgO}$ & 3,86 & 3,81 & 1,29 & 3,40 & 1,17 \\
\hline $\mathrm{Fe}_{2} \mathrm{O}_{3}$ & 1,98 & 2,18 & 2,12 & 2,51 & 4,75 \\
\hline $\mathrm{MnO}$ & 0,13 & 0,12 & 0,04 & 0,12 & 0,05 \\
\hline $\mathrm{TiO}_{2}$ & 0,08 & 0,03 & 0,01 & 0,00 & 0,01 \\
\hline $\mathrm{Na}_{2} \mathrm{O}$ & 0,44 & 0,41 & 26,32 & 0,52 & 31,14 \\
\hline $\mathrm{K}_{2} \mathrm{O}$ & 1,04 & 1,49 & 0,58 & 0,86 & 0,43 \\
\hline $\mathrm{P}_{2} \mathrm{O}_{5}$ & 38,08 & 21,19 & 8,70 & 33,09 & 20,68 \\
\hline $\mathrm{BaO}$ & 0,05 & 0,08 & 0,03 & 0,10 & 0,05 \\
\hline $\mathrm{SO}_{3}$ & 0,61 & 1,06 & 17,45 & 2,08 & 30,37 \\
\hline
\end{tabular}


dopuszczalne są tylko w formie nierozpuszczalnej, jako $\mathrm{BaSO}_{4}$. Zawartość $\mathrm{P}_{2} \mathrm{O}_{5}$ (do ok. 15\%) optymalizuje lepkość fazy szklistej podczas spiekania. Obecność fazy szklistej umożliwia immobilizację metali przejściowych i alkalicznych (Sitarz i in. 2012). W badanych odpadach zawartość fosforu dochodzi do 38\%, związana jest z jego obecnością w osadach ściekowych (Bień i Wystalska 2011; Szaja 2013) i nie stanowi bariery dla stosowania badanych odpadów w ceramice.

Zawartość metali przejściowych (tab. 3) takich jak ołów, cynk, miedź czy kadm zależy od pierwotnej ich koncentracji w osadzie ściekowym (Bień i Wystalska 2011; Szymański i in. 2011). We wszystkich próbkach zaobserwowano wysokie zawartości miedzi i cynku; mogą one stanowić problem o ile tworzą związki rozpuszczalne, które migrują do wody. W tym celu w dalszych badaniach przeprowadzono serię testów wymywalności. Obecność metali przejściowych w postaci związków nierozpuszczalnych nie stanowi zagrożenia w przypadku materiałów ceramiki czerwonej, zarówno na etapie ich produkcji jak i późniejszego użytkowania.

Tabela 3. Zawartości metali przejściowych w próbkach stałych pozostałości ze spalania komunalnych osadów ściekowych $[\mathrm{mg} / \mathrm{kg}]$

Table 3. The content of metals in incinerated sewage sludge solid residues $[\mathrm{mg} / \mathrm{kg}]$

\begin{tabular}{|c|c|c|c|c|c|}
\hline Metale przejściowe & G2 & K1 & KN1 & L1 & LN1 \\
\hline $\mathrm{Zn}$ & 3567 & 3280 & 1297 & 3242 & 1765 \\
\hline $\mathrm{Cu}$ & 886 & 528 & 193 & 728 & 378 \\
\hline $\mathrm{Pb}$ & 64,40 & 104 & 43,2 & 61,20 & 31,40 \\
\hline $\mathrm{Cd}$ & 3,94 & 5,90 & 2,36 & 3,61 & 2,02 \\
\hline $\mathrm{Cr}$ & 94,50 & 79,40 & 31,50 & 858 & 344 \\
\hline $\mathrm{Ni}$ & 53,10 & 60,60 & 27,20 & 80,20 & 42,90 \\
\hline $\mathrm{Co}$ & 9,71 & 17,60 & 8,07 & 13,57 & 6,95 \\
\hline $\mathrm{Hg}$ & 0,21 & 0,14 & 10,12 & 0,25 & 35,90 \\
\hline
\end{tabular}

\subsection{Skład fazowy}

Tak jak w przypadku składu chemicznego tak i skład fazowy badanych stałych pozostałości z instalacji TPKOŚ związany jest $\mathrm{z}$ ich rodzajem, a więc z miejscem ich powstawania. Analiza składu fazowego niezbędna jest do określenia w jakim minerale oraz w jakim układzie krystalograficznym występują dane tlenki, co w dalszej kolejności wpływa na ustalenie składu surowcowego masy plastycznej. Popioły lotne G2, K1 oraz L1 zawieraja głównie w swoim składzie kwarc, hematyt, anhydryt oraz związki fosforanowe wapnia i magnezu - rysunek 2. Pozostałości LN1 i KN1 zawierają wspomniane fazy jednak w mniejszych ilościach, natomiast dominującymi są w nich fazy tworzące się podczas procesu oczyszczania spalin: siarczan sodu (tenardyt) oraz $\mathrm{Na}_{6}\left(\mathrm{CO}_{3}\right)\left(\mathrm{SO}_{4}\right)_{2}$. 


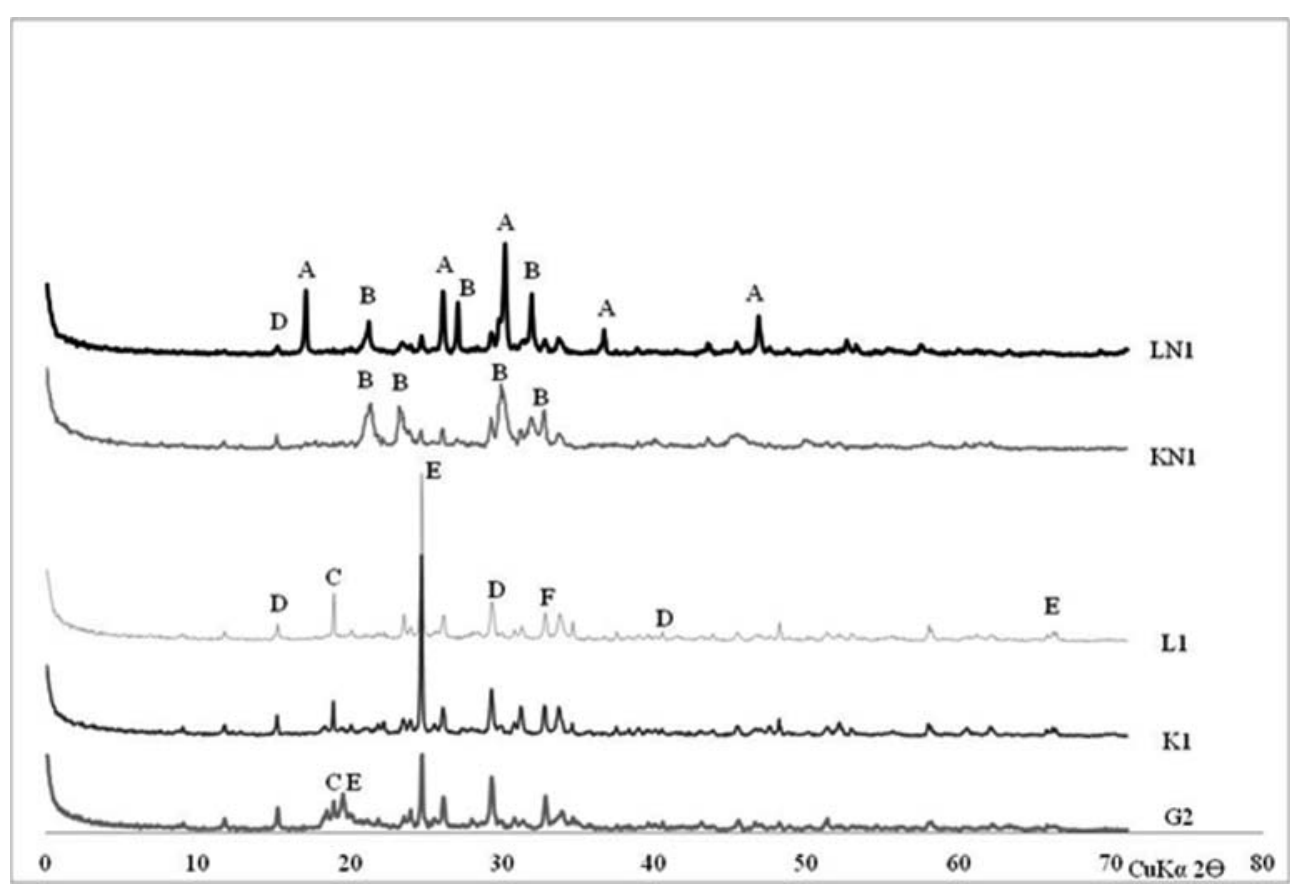

Rys. 2. Dyfraktogramy stałych pozostałości ze spalania komunalnych osadów ściekowych $\mathrm{A}-\mathrm{Na}_{2} \mathrm{SO}_{4}, \mathrm{~B}-\mathrm{Na}_{6}\left(\mathrm{CO}_{3}\right)\left(\mathrm{SO}_{4}\right)_{2}, \mathrm{C}-\mathrm{Fe}_{2} \mathrm{O}_{3}, \mathrm{D}-\mathrm{Ca}_{7} \mathrm{Mg}_{2} \mathrm{P}_{6} \mathrm{O}_{24}, \mathrm{E}-\mathrm{SiO}_{2}, \mathrm{~F}-\mathrm{CaSO}_{4}$

Fig. 2. X-ray diffraction patterns of incinerated sewage sludge solid residues

\subsection{Wymywalność zanieczyszczeń chemicznych}

Materiały ceramiczne elewacyjne są ciągle narażone na zmiany wilgotności, a więc zawartość związków rozpuszczalnych powinna w nich być możliwie jak najmniejsza. Przede wszystkim dotyczy to chlorków, siarczanów i metali ciężkich, które są szczególnie niebezpieczne ze względu na możliwość ich migracji do gleb i wód gruntowych. $Z$ tego powodu wyniki wymywalności zanieczyszczeń chemicznych z badanych odpadów porównano z dopuszczalnymi zawartościami w ściekach, które mogą być wprowadzone do wód lub do ziemi (Rozporządzenie MŚ 2014).

Wyniki testów pozwalających ocenić wymywalność zanieczyszczeń chemicznych z badanych odpadów zamieszczono w tabelach 4-6. Odczyn $\mathrm{pH}$ wody tylko w przypadku próby G2 pozostaje neutralny, w pozostałych przypadkach jest silnie zasadowy, co potwierdza wymywanie się alkaliów. Potencjał oksydacyjno-redukcyjny zmienia swoją wartość od -22 do $260 \mathrm{mV}$ w zależności od rodzaju badanej próbki. Wysokie wartości tego potencjału świadczą o niestabilnym układzie chemicznym, co można zaobserwować w przypadku próbki G2. Ogólna mineralizacja wyznaczana na podstawie przewodności, oznaczająca zawartość rozpuszczonych soli, jest bardzo wysoka w przypadku próbek KN1 i LN1 w porównaniu do próbek popiołów lotnych G2, K1, L1. 
Tabela 4. Parametry wyciągu wodnego po procesie ługowania

Table 4. Properties of leaching test water

\begin{tabular}{|l|c|c|c|c|c|}
\hline Parametry wyługowanej wody & G2 & K1 & KN1 & L1 & LN1 \\
\hline $\mathrm{pH}$ & 6,56 & 11,54 & 10,52 & 11,46 & 10,2 \\
\hline Eh [mV] & 260 & 40 & -22 & 79 & 68 \\
\hline Mineralizacja $\left[\mathrm{mg} / \mathrm{dm}^{3}\right]$ & 1548 & 1470 & 59632 & 1665 & 76359 \\
\hline Przewodność $[\mathrm{mS} / \mathrm{cm}]$ & 1,77 & 2,21 & 51,7 & 2,19 & 53,8 \\
\hline
\end{tabular}

Tabela 5. Wymywalność kationów metali alkalicznych i przejściowych z badanych odpadów [mg/dm³

Table 5. Cations leaching test of incinerated sewage sludge solid residues $\left[\mathrm{mg} / \mathrm{dm}^{3}\right]$

\begin{tabular}{|c|c|c|c|c|c|c|}
\hline Kationy & G2 & $\mathrm{K} 1$ & $\mathrm{KN} 1$ & $\mathrm{~L} 1$ & $\mathrm{LN} 1$ & $\begin{array}{c}\text { Wartości dopuszczalne } \\
\text { określone } \\
\text { Wozporządzenie } \\
\text { MŚ 2014) }\end{array}$ \\
\hline $\mathrm{Na}^{+}$ & 53,86 & 27,65 & 19360 & 86,60 & 23650 & 800 \\
\hline $\mathrm{K}^{+}$ & 62,80 & 74,72 & 84,12 & 22,14 & 104,5 & 80 \\
\hline $\mathrm{Ca}^{+2}$ & 227,30 & 379,2 & 17,08 & 429,2 & 118,9 & - \\
\hline $\mathrm{Mg}^{+2}$ & 91,17 & 0,15 & 9,23 & 0,36 & 12,32 & - \\
\hline $\begin{array}{c}\Sigma \mathrm{metali} \\
\mathrm{przejściowych}\end{array}$ & 0,2247 & 0,1026 & 1,3007 & 0,0265 & 0,2198 & \\
\hline $\begin{array}{c}\mathrm{Zn}, \mathrm{Cu}, \mathrm{Pb}, \mathrm{Cd}, \\
\mathrm{Cr}, \mathrm{Ni}, \mathrm{As}, \mathrm{Co}, \mathrm{Hg}\end{array}$ & & & & & & 3,65 \\
\hline
\end{tabular}

Tabela 6. Wymywalność anionów z badanych odpadów $\left[\mathrm{mg} / \mathrm{dm}^{3}\right]$

Table 6. Anions leaching test of incinerated sewage sludge solid residues $\left[\mathrm{mg} / \mathrm{dm}^{3}\right]$

\begin{tabular}{|c|c|c|c|c|c|c|}
\hline Aniony & $\mathrm{G} 2$ & $\mathrm{~K} 1$ & $\mathrm{KN} 1$ & $\mathrm{~L} 1$ & $\mathrm{LN} 1$ & $\begin{array}{c}\text { Wartości dopuszczalne } \\
\text { określone } \\
\text { (Rozporządzenie } \\
\text { MŚ 2014) }\end{array}$ \\
\hline $\mathrm{F}^{-}$ & 4,93 & 1,27 & 81,5 & - & - & 25 \\
\hline $\mathrm{Cl}^{-}$ & 6,70 & 53,5 & 190,7 & 4,4 & 2199 & 1000 \\
\hline $\mathrm{SO}_{4}{ }^{2-}$ & 924,6 & 857,9 & 30120 & 1034 & 49710 & 500 \\
\hline $\mathrm{HCO}_{3}{ }^{-}$ & 116,7 & - & 7153 & 0,5 & 471 & - \\
\hline $\mathrm{CO}_{3}{ }^{2-}$ & $>0,5$ & 19,3 & 2590 & 25,0 & 73,0 & - \\
\hline $\mathrm{PO}_{4}{ }^{3-}$ & 38,01 & 0,02 & 6,34 & 0,15 & 8,69 & fosfor ogólny \\
\hline
\end{tabular}


Mimo bardzo wysokich zawartości Zn i Cu w obu rodzajach odpadów, ich wymywalność jest znacznie niższa niż dopuszczalna dla ścieków, które mogą być wprowadzone do wód lub do ziemi. Prawdopodobnie jest to związane $\mathrm{z}$ występowaniem tych metali w formach nierozpuszczalnych w wodzie. Podobnie jest dla wymywalności pozostałych metali ciężkich - tabela 5. Zawartość siarczanów w wyciagu wodnym dla wszystkich popiołów jest wyższa od dopuszczalnej i przekracza $500 \mathrm{mg} / \mathrm{dm}^{3}$, szczególnie dla próbek KN1 i LN1, w przypadku popiołu LN1 przekroczona jest również zawartość chlorków (pow. $1000 \mathrm{mg} / \mathrm{dm}^{3}$ ) - tabela 6 .

\section{Wnioski}

W artykule przedstawiono wyniki badań stałych pozostałości z termicznego przekształcania komunalnych osadów ściekowych w kotłach fluidalnych w trzech instalacjach. Badano próbki popiołów lotnych oraz pozostałości z procesów oczyszczania spalin z kwaśnych zanieczyszczeń i metali ciężkich. Badania wykonano pod kątem możliwości ich wykorzystania jako składników do produkcji cegieł, częściowo zastępujących piasek i/lub materiały plastyczne.

Badane odpady głównie zawierają kwarc, a zawartość w jednej próbce popiołu lotnego wynosi powyżej 43\%, która z punktu widzenia właściwości schudzających, ograniczających nadmierną plastyczność, powodującą odkształcenia materiału podczas procesu suszenia i wypalania, jest korzystna. Krzemionka ma również zasadniczy wpływ na prawidłową lepkość fazy ciekłej, która powstaje podczas wypalania. Ogólna zawartość alkaliów (sód i potas) do $1 \%$ pozwala w sposób kontrolowany obniżyć temperaturę wypalania wyrobów, a co za tym idzie redukować zapotrzebowanie energetyczne procesu. Problemem jest jednak zbyt duża ich ilość w przypadku pozostałości z procesów oczyszczania spalin z kwaśnych zanieczyszczeń gazowych i metali ciężkich.

Zawartości izotopów promieniotwórczych w badanych próbkach nie przekraczają dopuszczalnych norm, dlatego pod tym względem mogą być stosowane w materiałach budowlanych przewidzianych to stałego zamieszkania przez ludzi.

Występujące $w$ badanych próbkach odpadów metale ziem alkalicznych czyli wapń i magnez, wydłużają interwał spiekania, co z punktu widzenia technologii produkcji jest bardzo pozytywnym zjawiskiem. Zawartość tlenków barwiących w surowcach jest cechą niepożądaną, dlatego użycie składników ze znaczną zawartością tlenków żelaza, tytanu lub manganu jest niemożliwa $\mathrm{w}$ ceramice stołowej czy sanitarnej. W przypadku ceramiki czerwonej obecność tych tlenków nie ma większego znaczenia.

Wymywalność metali z badanych odpadów jest znacznie niższa niż wartości dopuszczalne, a więc nie ma zagrożeń migracji szkodliwych kationów do gleby i wód gruntowych. Wyjątek stanowią pozostałości z oczyszczania spalin z kwaśnych zanieczyszczeń gazowych i metali ciężkich, z których wymywalność sodu przekracza dopuszczalne wartości. W przypadku anionów problem stanowi wymywalność chlorków i siarczanów, które przekraczają 
dopuszczalne wartości (szczególnie dla pozostałości z oczyszczania spalin z kwaśnych zanieczyszczeń i metali ciężkich) i będą powodowały wady materiałowe w postaci wykwitów solnych oraz zagrożenie środowiska.

Wykonane badania stanowią pierwszy etap badań przy określaniu możliwości zastosowania stałych pozostałości z termicznego przekształcania komunalnych osadów ściekowych w przemyśle ceramiki czerwonej do produkcji cegieł. Na podstawie określonych właściwości fizykochemicznych można stwierdzić, że potencjalnie mogą być zastosowane w tym kierunku tylko popioły lotne, co będzie przedmiotem dalszych badań.

Artykut powstat $w$ wyniku realizacji grantu dziekańskiego $\mathrm{nr}$ 15.11.100.710 oraz prac statutowych, $n$ r 11.11.100.482

\section{LITERATURA}

Ahmaruzzaman, M., 2010. A review on the utilization of fly ash. Progress in Energy and Combustion Science 36, s. $327-363$.

Anderson, M. i Skerratt, R.G. 2003. Variability study of incinerated sewage sludge ash in relationto future use in ceramic brick manufacture. British Ceramic Transactions 102(3), s. 109-113.

Bień, J.B. i Wystalska, K. 2011. Osady ściekowe, teoria i praktyka. Częstochowa: Wydawnictwo Politechniki Częstochowskiej.

Borowski, G. 2012. Ocena przydatności zeszkliwienia osadów ściekowych do ich zagospodarowania. Ochrona Środowiska i Zasobów Naturalnych $\mathrm{Nr}$ 51, s. 78-84.

Cheng, T.W. i Chen, Y.S. 2004. Characterisation of glass ceramics made from incinerator fly ash. Ceramics International 30, s. 343-349.

Cultrone, G. i Sebastián, E. 2009. Fly ash addition in clayey materials to improve the quality of solid bricks. Construction and Building Materials Vol. 23, Issue 2, s. 1178-1184.

Cyr i in. 2007 - Cyr, M., Coutand, M. i Clastres, P. 2007. Technological and environmental behavior of sewage sludge ash (SSA) in cement-based materials. Cement and Concrete Research 37, s. 1278-1289.

Donatello, S. i Cheeseman, C.R. 2013. Recycling and recovery routes for incinerated sewage sludge ash (ISSA): A review. Waste Management vol. 33, s. 2328-2340.

Galos, K. 2008. Analiza dotychczasowych badań krajowej bazy zasobowej głównych kopalin ceramicznych ze wskazaniem niezbędnego zakresu dalszych prac. Gospodarka Surowcami Mineralnymi-Mineral Resources Management t. 24, z. 4/4, s. 53-73.

Gunn i. in. 2004 - Gunn, A., Dewhurst, R., Giorgetti, A., Gillot, N., Wishart, J. i Pedley, S., 2004. Use of sewage sludge in construction. CIRIA. C608. London.

GUS 2013. Ochrona Środowiska 2013. Informacje i Opracowania Statystyczne. Główny Urząd Statystyczny. Warszawa 2013.

Iżewska, A. i Wołoszyk, C. 2014. Wpływ nawożenia popiołem ze spalania komunalnych osadów ściekowych na właściwości chemiczne gleby lekkiej. Annual Set The Environment Protection Vol. 16, s. 486-497.

Kępys i in. 2014 - Kępys, W., Pomykała, R. i Pietrzyk, J. 2014. Badania właściwości zawiesin popiołowo-wodnych z popiołów ze spalania komunalnych osadów ściekowych. Inżynieria Mineralna nr 1.

Lin, K.L. 2006. Feasibility study of using brick made from municipal solid waste incinerator fly ash slag. Journal of Hazardous Materials B137, pp. 1810-1816.

Lin, D. i Weng, C. 2001. Use of sewage sludge ash as brick material. Journal of Environmental Engineering Vol. 127, no. 10, s. 922-927.

Małolepszy, J. red. 2004. Materiały budowlane. Kraków: Uczelniane Wydawnictwa Naukowo-Dydaktyczne $\mathrm{AGH}$. 
Monzó i in. 2003 - Monzó, J., Payá, J., Borrachero, M.V. i Girbeś, I. 2003. Reuse of sewage sludge ashes (SSA) in cement mixtures: the effect of SSA on the workability of cement mortars. Waste Management 23, s. 373-381.

Ottosen i in. 2013 - Ottosen, L.M, Kirkelund, G.M. i Jensen, P.E. 2013. Extracting phosphorous from incinerated sewage sludge ash rich in iron or aluminum. Chemosphere Vol. 91, Issue 7, s. 963-969.

Pietrzyk, J. 2012. Rola procesów termicznych w zagospodarowaniu komunalnych osadów ściekowych. Materiały Krakowskiej Konferencji Młodych Uczonych, Kraków 2012. Grupa Naukowa Pro Futuro. Fundacja dla $\mathrm{AGH}$

PN-EN 12457-2. Charakteryzowanie odpadów - Wymywanie - Badanie zgodności w odniesieniu do wymywania ziarnistych materiałów odpadowych i osadów - Część 2: Jednostopniowe badanie porcjowe przy stosunku cieczy do fazy stałej 10 1/kg w przypadku materiałów o wielkości cząstek poniżej 4 mm (bez redukcji lub $\mathrm{z}$ redukcją wielkości).

Rozporządzenie MG 2013. Rozporządzenie Ministra Gospodarki z dnia 8 stycznia 2013 r. w sprawie kryteriów oraz procedur dopuszczania odpadów do składowania na składowisku odpadów danego typu (Dz.U. 2013 nr 0 poz. 38).

Rozporządzenie MŚ 2001. Rozporządzenie Ministra Środowiska z dnia 27 września 2001 r. w sprawie katalogu odpadów (Dz.U. 2001 nr 112 poz. 1206).

Rozporządzenie MŚ 2006. Rozporządzenie Ministra Środowiska z dnia 24 lipca 2006 r. w sprawie warunków, jakie należy spełnić przy wprowadzaniu ścieków do wód lub do ziemi, oraz w sprawie substancji szczególnie szkodliwych dla środowiska wodnego (Dz.U. $2006 \mathrm{nr} 137$ poz. 984).

Rozporządzenie RM 2013. Rozporządzenie Rady Ministrów z dnia 2 stycznia 2007 r. w sprawie wymagań dotyczących zawartości naturalnych izotopów promieniotwórczych potasu K-40, radu Ra-226 i toru Th-228 w surowcach i materiałach stosowanych w budynkach przeznaczonych na pobyt ludzi i inwentarza żywego, a także w odpadach przemysłowych stosowanych w budownictwie, oraz kontroli zawartości tych izotopów (Dz.U. $2007 \mathrm{nr} 4$ poz. 29).

Sitarz i in. 2012 - Sitarz, M., Bułat, K. i Pszczoła, J. 2012. Krystalizacja szkieł krzemianowo fosforanowych z układu $\mathrm{CaNaPO}_{4}-\mathrm{SiO}_{2}$. Materiaty Ceramiczne vol. 64/3, s. 364-366.

Szaja, A. 2013. Phosphorus Recovery from Sewage Sludge via Pyrolysis. Annual Set The Environment Protection Vol. 15, s. 361-370.

Szymański i in. 2011 - Szymański, K., Janowska, B. i Jastrzębski, P. 2011. Heavy Metal Compounds in Wastewater and Sewage Sludge. Annual Set The Environment Protection Vol. 13, s. 83-100.

Wainwright, P.J. i Cresswell, D.J.F. 2001. Synthetic aggregates from combustion ashes using an innovative rotary kiln. Waste Management 21, s. 241-246.

Weigand i in. 2013 - Weigand, H., Bertau, M., Hübner, W., Bohndick, F. i Bruckert, A. 2013. Full-scale fertilizer production from sewage sludge ash. Waste Management Vol. 33, Issue 3, s. 540-544.

Weng i in. 2003 - Weng, C.H., Lin, D.F., Chiang P.C. Utilization of sludge as brick materials. Advances in Environmental Research Vol 7, s. 679-685.

Wzorek, Z. 2008. Odzysk zwiazków fosforu z termicznie przetworzonych odpadów i ich zastosowanie jako substytutu naturalnych surowców fosforowych. Seria Inżynieria i Technologia Chemiczna. Kraków. Wyd. PK.

Xu 2012 - Xu, H., He, P., Gu, W., Wang, G. i Shao, L. 2012. Recovery of phosphorus as struvite from sewage sludge ash. Journal of Environmental Sciences Vol. 24, Issue 8, s. 1533-1538.

Zhang, L. 2013. Production of bricks from waste materials - A review. Construction and Building Materials 47 , s. $643-655$. 
WPLYW WLAŚCIWOŚCI FIZYKOCHEMICZNYCH STALYCH POZOSTALOŚCI

Z TERMICZNEGO PRZEKSZTALCANIA OSADÓW ŚCIEKOWYCH NA MOŻLIWOŚĆ ICH WYKORZYSTANIA W CERAMICE CZERWONEJ

\author{
Słowa kluczowe
}

spalanie komunalnych osadów ściekowych, stałe pozostałości, produkcja cegieł

\title{
Streszczenie
}

Przedmiotem niniejszej pracy jest przedstawienie właściwości fizykochemicznych stałych pozostałości z termicznego przekształcania komunalnych osadów ściekowych w aspekcie wykorzystania ich w produkcji ceramiki czerwonej. Wykorzystanie tego rodzaju odpadów jest sposobem na ich zagospodarowanie, a ponadto może wpłynąć na redukcję kosztów produkcji cegieł, przy zachowaniu założonych parametrów użytkowych oraz walorów estetycznych. Określono skład chemiczny i mineralny stałych pozostałości, zawartość naturalnych izotopów promieniotwórczych, skład granulometryczny oraz wymywalność soli rozpuszczalnych, mogących stanowić potencjalne zagrożenie oraz powodować wady materiałowe.

Kwarc stanowi główny składnik fazowy analizowanych materiałów, a jego zawartość dochodzi do $43 \%$ wag. Ilość ta $\mathrm{z}$ punktu widzenia właściwości ograniczających nadmierną plastyczność, powodującą odkształcenia materiału podczas procesu suszenia i wypalania, jest korzystna a popiół może być wykorzystany jako materiał schudzający, czyli substytut piasku.

Jedną z najczęstszych wad materiałowych ceramiki budowlanej jest powstawanie wykwitów solnych podczas kontaktu z wilgocią. Wykwity te spowodowane są obecnością w surowcach rozpuszczalnych w wodzie jonów siarczanowych, które podczas użytkowania wyrobów migrują w porach i krystalizują na powierzchni w postaci białych osadów. Popioły KN1 i LN1 charakteryzują się bardzo wysoką zawartością tych jonów, wynikającą z procesu oczyszczania spalin (stosowanie wodorowęglanu sodu), mogą być poważnym utrudnieniem w technologii produkcji cegieł, wręcz wykluczającym ich stosowanie w tym kierunku.

Popioły zawierają w swoim składzie metale, które potencjalnie mogą stanowić zagrożenie środowiska, szczególnie wysoką koncentrację zaobserwowano w przypadku kationów miedzi i cynku. Badania wykazały, że tworzą one związki nierozpuszczalne, a ich wymywalność jest znacznie niższa niż wartości graniczne, a więc nie ma zagrożeń migracji szkodliwych kationów do gleby i wód gruntowych. 
THE INFLUENCE OF INCINERATED SEWAGE SLUDGE ASHES PHYSICAL

AND CHEMICAL PROPERTIES IN POSIBILITY OF USAGE IN RED CERAMIC

Keywords

sewage sludge incineration, ash characteristics, ceramic bricks, alternative materials

Abstract

The purpose of this case study is to investigate the properties and performance of sewage sludge ash from five specific sources such as plants incineratied as municipal sewage sludge in different part of Poland. The use of sludge as a construction and building material converts the waste into useful products that can alleviate disposal issues. Alternative materials are being considered for use by brick manufacturers as a potential cost effective solution to access materials with desirable compounds and properties that will satisfy the demand for large portfolios of products with different aesthetic properties. Testing is carried out to identify the properties and characteristics of alternative materials, as well as to determine whether the inclusion of certain alternative materials provide desirable results during lab-based experimentation. Special attention has been paid on ash mineralogy and chemical composition; particle size distribution; anion and cation leaching, which can be potentially dangerous and cause materials defects.

The main component of the examined sewage sludge ashes is quartz, more than $43 \%$ so the ash can be good weakening agent (substitute for a sand), the material which causes increasing mass shrinkage during drying and sintering (too big shrinkage is the reason of material distortion). Quartz also allows the proper viscosity of liquid phase to be obtained during sintering.

One of the most serious problem in bricks are salts efflorescences. It is caused by soluble salts in solution being brought to the surface as the water in the wall dries out. Efflorescence is caused by a number of soluble salts including the sulphate or carbonate compounds of calcium, sodium, potassium and magnesium. Ashes KN1 and LN1 have huge contents of sulphides and are qualified as hazardous when using them as a substitute materials in the technology of brick production.

Transition metal concentrations (e.g., lead, cadmium, zinc, copper) are usually found in sludge ash, however leaching tests allows one to see any measurable leaching problem. Despite high concentrations of $\mathrm{Zn}$ and $\mathrm{Cu}$ in samples, their leachability is much lower than the permissible value for sludge which may be introduced into the water or the ground. It is probably related to the presence of these metals in the non-water-soluble forms. 